$\begin{array}{ll}\text { Abstracta Iranica } & \begin{array}{l}\text { Abstracta Iranica } \\ \text { Revue bibliographique pour le domaine irano-aryen }\end{array} \\ & \text { Volume } \mathbf{2 8} \mid \mathbf{2 0 0 7} \\ & \text { Comptes rendus des publications de } \mathbf{2 0 0 5}\end{array}$

Kiarostami. Rome, Electa, 2003, 223 p.

Agnès Devictor

(2) OpenEdition

Journals

Édition électronique

URL : http://journals.openedition.org/abstractairanica/7342

DOI : 10.4000/abstractairanica.7342

ISSN : 1961-960X

Éditeur :

CNRS (UMR 7528 Mondes iraniens et indiens), Éditions de l'IFRI

Édition imprimée

Date de publication : 15 mai 2007

ISSN : 0240-8910

Référence électronique

Agnès Devictor, « Kiarostami. Rome, Electa, 2003, 223 p. », Abstracta Iranica [En ligne], Volume 28 | 2007, document 530, mis en ligne le 18 septembre 2007, consulté le 25 septembre 2020. URL : http:// journals.openedition.org/abstractairanica/7342; DOI : https://doi.org/10.4000/abstractairanica.7342

Ce document a été généré automatiquement le 25 septembre 2020.

Tous droits réservés 


\section{Kiarostami. Rome, Electa, 2003, 223}

p.

Agnès Devictor

1 Cet ouvrage collectif, publié en italien à l'occasion de la grande manifestation « Sur les routes de Kiarostami. Cinéma. Photographie. Vidéo. Poésie » (Turin 18 sept-12 octobre 2003) présente l'œuvre du cinéaste dans les différentes voies esthétiques qu'il explore. On notera notamment un texte de Kiārostamī «Deux ou trois choses que je sais de moi », «Abbas Kiarostami, un artiste du cinéma » et «Le Tazieh de Kiarostami » de Jean-Michel Frodon, «L'enfant, la loi et l'agencement » d'Alain Bergala et «Garder le regard. Pour une grammaire des images » de Marco Vallora. Cet ouvrage comporte aussi une filmographie détaillée et commentée, une bibliographie exhaustive, un très grand nombre de photographies du cinéaste (dans une bonne qualité de tirage) et quatre poésies inédites de Kīārostamī.

\section{INDEX}

Thèmes : 17.2. Arts du spectacle

\section{AUTEURS}

AGNÈS DEVICTOR

Université d'Avignon 